Research Article

\title{
Tamarix articulata Extracts Exhibit Antioxidant Activity and Offer Protection against Hydrogen Peroxide-Mediated Toxicity to Human Skin Fibroblasts
}

\author{
Abdullah M. Alnuqaydan \\ Department of Medical Biotechnology, College of Applied Medical Sciences, Qassim University, Buraydah, Saudi Arabia \\ Correspondence should be addressed to Abdullah M. Alnuqaydan; ami.alnuqaydan@qu.edu.sa
}

Received 27 July 2020; Revised 10 October 2020; Accepted 7 November 2020; Published 21 November 2020

Academic Editor: Valerio Matozzo

Copyright (C) 2020 Abdullah M. Alnuqaydan. This is an open access article distributed under the Creative Commons Attribution License, which permits unrestricted use, distribution, and reproduction in any medium, provided the original work is properly cited.

\begin{abstract}
Tamarix articulata (TA) is a wild halophytic plant growing in extremely harsh environmental conditions in the deserts of Saudi Arabia. Evaluating the protective effect of the methanolic extract of different parts (fresh and dry leaves, stem, and root) of TA was determined by MTT assay using Hs27 skin fibroblasts as the cellular model. The study was designed and conducted in two sets. The first set assesses the toxicity profile of TA extracts in both concentration- and time-dependent ways on Hs27 cells. Our MTT results showed that methanolic extracts from all four parts of TA at varying doses $(27.5,55,110$, and $220 \mu \mathrm{g} / \mathrm{mL})$ display negligible toxicity when exposed for $4 \mathrm{~h}$. However, exposure of Hs27 cells to varying doses of all four TA extracts for 24 and $48 \mathrm{~h}$ promotes significant $23 \%, 24 \%, 26 \%$, and $25 \%(p<0.05)$ and $35 \%, 36 \%, 39 \%$, and $41 \%(p<0.05)$ cell toxicity at $220 \mu \mathrm{g} / \mathrm{mL}$ of all four TA extracts compared to untreated control cells. To evaluate the protection offered by TA extracts against $\mathrm{H}_{2} \mathrm{O}_{2}$, we perform a second set of experiments to preincubate Hs27 cells with the TA extracts in both dose- and time-dependent way. This is followed by $300 \mu \mathrm{M}$ hydrogen peroxide- $\left(\mathrm{H}_{2} \mathrm{O}_{2}-\right)$ mediated oxidative insult for $1 \mathrm{~h}$. Using MTT assay, we found that methanolic extracts of TA at different time points $(4,24$, and $48 \mathrm{~h})$ and higher doses $(220 \mu \mathrm{g} / \mathrm{mL})$ provide significant protection in cell viability when challenged with $\mathrm{H}_{2} \mathrm{O}_{2}$-induced oxidative stress in $\mathrm{Hs} 27$ cells. The protective effect was more pronounced at $48 \mathrm{~h}$ and $220 \mu \mathrm{g} / \mathrm{mL}$ and the amounts were $39 \%, 41 \%, 41 \%$, and $44 \%$ for stem, root, fresh leaf, and dry leaf TA extracts $(p<0.05)$, respectively, compared to untreated cells $(2-4 \%)$. Collectively, the current study demonstrates that methanolic extracts of TA contain potential bioactive compounds and offer significant protection against $\mathrm{H}_{2} \mathrm{O}_{2}$-mediated oxidative stress in $\mathrm{Hs} 27$ skin fibroblasts.
\end{abstract}

\section{Introduction}

Polyphenolic bioactive compounds derived from plants are of great importance in the medical sciences because of their therapeutic potential as chronic disease protectors and chemopreventive agents [1]. Owing to their chelating and antioxidant activities, polyphenolic bioactive compounds act as free radical scavengers and neutralize dangerous reactive oxygen species (ROS) [2]. Previous reports in the field of free radical biology revealed that free radicals play a crucial role in the pathophysiology of many chronic diseases including cancer [3]. High level of free radical oxygen species including singlet oxygen, superoxide anion, and $\mathrm{H}_{2} \mathrm{O}_{2}$ promotes oxidative stress cells. These free radicals are unstable and extremely harmful for the biological system; they interact with cellular components and cause damage to cell membrane proteins, lipids, and DNA molecules [4]. The antioxidants within the cells function by firstly scavenging and neutralizing the production of free radicals to prevent any damage and secondly making inroads to disrupt potentially destructive reactions [5].

The major sources of antioxidants are plants and their derived products such as fruits [6]. Plant and herbal products have been studied previously to evaluate their antioxidant potential against oxidative stress [7]. Currently, plant-derived products that are abundant in antioxidants are receiving more attention because they offer numerous health benefits [8]. These plant-derived 
products contain phenolic compounds which display antioxidant properties [9]. Owing to many phenolic hydroxyl groups, these compounds can scavenge free radicals through the phenoxide ion delocalization process [10].

Tamarix articulata (TA) which is commonly called Athal in the Arabic language is a halophytic plant [11]. Owing to its fine interaction with salinity regulated microbial communities to maintain optimum salt concentration around the roots, the plant can grow in extremely harsh conditions [12]. The plant belongs to the Tamaricaceae family and may reach a height of 20 meters [13]. From ancient times, TA has been used as a fork medicine by the Tafilalet population-a tribal people in the south-eastern region of Morocco-against various ailments including hair loss, hypertension, ulcers, and gastrointestinal disturbances $[14,15]$. Previous findings revealed the presence of numerous bioactive compounds in TA extract exhibit curative effects against epilepsy [15]. The major phytochemical constituents of TA extract which are responsible for pharmacological activities of TA extract are presented in Table 1 [21]. Additionally, dry leaves of TA have been used to cure skin diseases in Saudi Arabia [22]. Preliminary studies have revealed that the extract of TA from the Moroccan region reveals few biological activities [23]. Therefore, we investigate whether TA extract could also have the potential to protect cells against $\mathrm{H}_{2} \mathrm{O}_{2}$-mediated oxidative stress. Using cell cytotoxicity (MTT), the current study evaluates the cytotoxicity profile and antioxidant potential of methanolic extracts of TA after being challenged with hydrogen peroxide- $\left(\mathrm{H}_{2} \mathrm{O}_{2}-\right)$ mediated oxidative stress in Hs27 skin fibroblasts.

\section{Materials and Methods}

2.1. Collection of Plant Material and Preparation of Extracts. The plant material (TA) was collected in August 2019 from the desert regions of Qassim province of the Kingdom of Saudi Arabia.

Extracts of all parts of TA were formulated by the standard protocol mentioned in our previous article [24, 25]. All the parts (fresh leaves, dry leaves collected from the floor, stem, and root) were first air-dried in the shade to remove moisture completely. After being chopped into small pieces, all parts of TA were ground in a kitchen blender to produce a fine powder. After weighing $12 \mathrm{~g}$ of powder of each part of $\mathrm{TA}$, the power was added to $300 \mathrm{~mL}$ of $100 \%$ methanol and stirred constantly for 5 days at room temperature [24]. The mixture obtained after stirring was filtered through a cheesecloth to remove the bulk followed by filtering through a Whatman filter paper in an autoclaved glass beaker. Then the methanol (solvent) was completely evaporated from the plant extract mixture in a glass beaker by keeping the temperature of the hot plate at $45^{\circ} \mathrm{C}$. This was done to avoid degrading the heat labile compounds. Following this, the fine powder of residue was left in the glass beaker after the solvent's evaporation and stored at $4^{\circ} \mathrm{C}$ for future experiments to evaluate the biological activities of the TA plant.
2.2. Chemicals. The chemicals 1, 1,-diphenyl-2-picryl-hydroxyl (DPPH, \#D9132), dimethyl sulphoxide (DMSO, \#D8418), 3-(4, 5-dimethylthiazol-2-yl)-2, 5-diphenyltetrazolium bromide (MTT, \#M5655), Folin-Ciocalteu reagent (FCR, \#F9252), methanol (\#646377), fetal bovine serum (FBS, \#F0926), phosphate-buffered saline (PBS, \#3818), quercetin (QE, \#Q4951), and hydrogen peroxide $\left(\mathrm{H}_{2} \mathrm{O}_{2}\right.$, \#H1009) were procured from Sigma Aldrich.

2.3. Cell Culture and Treatments. Hs27 (human skin fibroblast) cell line was ordered and purchased from the American Type Culture Collection (ATCC). The cell line was cultured at Roswell Park Memorial Institute (RPMI)-1640 culture media added with $10 \%$ fetal bovine serum (FBS) and $1 \%$ penicillin-streptomycin solution under an aseptic condition in $5 \% \mathrm{CO}_{2}$ humidified incubator. The $\mathrm{Hs} 27$ cell line was regularly checked for Mycoplasma contamination.

2.4. Determination of Total Polyphenols. The determination of total phenols of TA extracts (methanolic) was determined by the standard Folin-Ciocalteu reagent (FCR) method. The standard compound gallic acid (GA) was taken as a reference compound to determine total phenols in the TA extract [26]. Briefly, $1 \mathrm{ml}$ each of FCR and extract $(1 \mathrm{mg} / \mathrm{mL})$ of various parts of TA in a glass tube were mixed properly using a vortex for 5 minutes. After proper mixing of the $3 \mathrm{ml}$ substance, sodium carbonate $(2 \%)$ was added, and the mixture was properly mixed again for $5 \mathrm{~min}$ to ensure this was thorough. The mixture in glass tubes was allowed to incubate in the dark for $3 \mathrm{~h}$ at room temperature. By using a spectrophotometer, the absorbance at $760 \mathrm{~nm}$ of each solution in the glass tubes was determined against the blank which contains all reagents except test samples or gallic acid under similar conditions. All the readings/absorbance were carried out in triplicate. The total polyphenolic content is expressed as milligrams of GA equivalent per gram dry weight (mg/GAE/g DW). The following formula was used to calculate the phenolic content:

$$
C=\frac{c \times V}{m} .
$$

Here, $C$ is total phenolic content expressed in $\mathrm{mg} \mathrm{GAE} / \mathrm{g}$ dry weight, $c$ is concentration of gallic acid in $\mathrm{mg} / \mathrm{mL} \mathrm{ob-}$ tained from the calibration curve, $V$ is volume of extract in $\mathrm{mL}$ used, and $m$ is mass of extract in g used.

\subsection{Determination of Total Antioxidant Capacity (TAC).}

The TAC of TA extracts was determined by a standard method [27] with only slight modifications. Briefly, $0.5 \mathrm{~mL}$ of varying concentrations of TA extracts along with standard compound (ascorbic acid) was mixed with a $3 \mathrm{~mL}$ mixture (1\% ammonium molybdate, $28 \mathrm{mM}$ sodium phosphate, and $0.6 \mathrm{M}$ sulphuric acid) in the test tubes. After ensuring complete mixing by gentle vortex, the mixtures in the glass test tubes were incubated for $10 \mathrm{~min}$ at $95^{\circ} \mathrm{C}$. Once the reaction was completed, the reaction mixture was cooled down at room temperature and using a spectrophotometer, optical density of the reaction 
TABLE 1: Major constituents of TA that exhibit pharmacological activity.

\begin{tabular}{|c|c|c|c|}
\hline $\begin{array}{l}\text { S. } \\
\text { no. }\end{array}$ & $\begin{array}{c}\text { Major } \\
\text { constituents }\end{array}$ & Functions & References \\
\hline 1 & Gallic acid & $\begin{array}{c}\text { Inhibits lipid peroxidation, promotes radical scavenging activity, and maintains endogenous defense } \\
\text { system }\end{array}$ & [16] \\
\hline 2 & Rutin & $\begin{array}{c}\text { Exhibits various pharmacological activities such as antioxidant, antidiabetic, anticonvulsant, and } \\
\text { neuroprotection activity. }\end{array}$ & {$[17]$} \\
\hline 3 & Naringin & $\begin{array}{c}\text { Exhibits promising antioxidant, antiproliferative, immunomodulatory, and immunostimulatory } \\
\text { potential in cellular models }\end{array}$ & [18] \\
\hline 4 & Quercetin & $\begin{array}{c}\text { Promising antioxidant and antiproliferative activity, inhibitory effect against acetyl cholinesterase } \\
\text { enzymes }\end{array}$ & [19] \\
\hline 5 & Chlorogenic acid & $\begin{array}{l}\text { Exhibits free radical scavenging activity, hepatoprotective activity, anti-inflammatory, and immune } \\
\text { modulation activity against various cellular models }\end{array}$ & [20] \\
\hline
\end{tabular}

mixture was measured at $695 \mathrm{~nm}$ after being normalized with a blank. Increase in optical density of the reaction mixture is directly proportional to the TAC of TA extracts.

\subsection{Hydroxyl Radical Scavenging Activity (HRSA). The} HRSA activity of TA extract was determined by standard method [28] with some modification. Briefly, $0.5 \mathrm{ml}$ of varying concentrations of TA extract along with standard was added into a glass test tube. Each test tube was added with $1 \mathrm{~mL}$ (0.85\% DMSO), $0.5 \mathrm{~mL}$ (0.018\% EDTA), $0.5 \mathrm{~mL}$ (22\% ascorbic acid), and $1 \mathrm{~mL}(0.13 \%$ iron $+0.26 \%$ EDTA solution). After adding these reagents and then capping tightly, the test tubes were incubated for $15 \mathrm{~min}$ at $85^{\circ} \mathrm{C}$. Immediately after incubation, the test tubes $\mathrm{mL}$ had $0.5 \mathrm{~mL}$ $17.5 \%$ precooled TCA added to them, followed by the addition of $3 \mathrm{~mL}$ of Nash reagent $(300 \mu \mathrm{L}$ glacial acetic acid, $7.5 \mathrm{~g}$ ammonium acetate, and $200 \mu \mathrm{L}$ acetyl acetone mixed in $100 \mathrm{~mL}$ distilled water) in each tube. They were then incubated for the next $15 \mathrm{~min}$ at room temperature. After incubation, the optical density of each solution in the test tubes was measured at $412 \mathrm{~nm}$ of wavelength utilizing a spectrophotometer. The percentage of HRSA was calculated by applying the following equation:

$$
\% \text { HRSA }=\frac{\text { absorbance of control }\left(A_{\mathrm{o}}\right)-\text { absorbance of TA extract }}{\text { standard compound }\left(A_{1}\right) / \text { absorbance of control }\left(A_{\mathrm{o}}\right)} \times 100
$$

The $\mathrm{IC}_{50}$ was calculated after calculating percentage of HRSA of varying concentrations of TA extract.

2.7. Cell Proliferation/Viability Assay. Cell viability was determined by a well-known MTT assay as per the standard protocol [29]. Briefly, $5 \times 10^{3} \mathrm{Hs} 27$ cells were harvested and plated in each well of the 96-well plate and subsequently attached to the bottom of the well overnight at $37^{\circ} \mathrm{C}$ in $5 \%$ $\mathrm{CO}_{2}$ humidified incubator. After they had properly adhered to the bottom surface of the well, the cells were exposed to the varying $(27.5 \mu \mathrm{g} / \mathrm{mL}$ to $220 \mu \mathrm{g} / \mathrm{mL})$ doses of each extract along with untreated control for $24 \mathrm{~h}$ in $5 \% \mathrm{CO}_{2}$ humidified incubator. Subsequently, after $24 \mathrm{~h}$, each well-containing cell had $20 \mu \mathrm{l}$ of MTT solution $(2.5 \mathrm{mg} / \mathrm{mL})$ added to it and incubated for 3 to $4 \mathrm{~h}$ at $37^{\circ} \mathrm{C}$ in $5 \% \mathrm{CO}_{2}$ humidified incubator. The formazan crystals formed by the interaction of MTT dye with succinyl dehydrogenase of mitochondria of live cells were dissolved in DMSO. The solution thus obtained appears to be measured at $570 \mathrm{~nm}$ wavelength using a multiplate reader. The absorbance recorded was analyzed and results were expressed as percentage cell viability of TA extract-treated cells compared to the untreated control cells.

2.8. Statistical Analysis. To obtain the data from all the experiments, the process was done more than three times.
The data analysis of all the independent experiments was performed and analyzed utilizing one-way ANOVA. The data were expressed as the mean of \pm SE. The $p$ value equal to or less than 0.05 is said to be significant.

\section{Results and Discussion}

3.1. Characteristics of TA Extract. Using absolute methanol as solvent for all four parts of TA (dry and fresh leaves, stem, and root) extraction by constant stirring for 5 days, the amount $(\mathrm{g} / 100 \mathrm{~g})$ of yield extracted from all four parts was the highest in dry leaves (12.78\%) followed by fresh leaves $(9.87 \%)$, root $(9.13 \%)$, and stem $(8.34 \%)$ as shown in Table 2. The determination of polyphenol content was analyzed by Folin-Ciocalteu assay which was expressed as gallic acid equivalent (GAE) per gram of extract. As shown in Table 2, the polyphenol content for all four extracts of TA is $409.92 \mathrm{mg} \mathrm{GAE} / \mathrm{g}$ for dry leaf extract followed by $387.08 \mathrm{mg}$ $\mathrm{GAE} / \mathrm{g}$ for root extract, $141.75 \mathrm{mg} \mathrm{GAE} / \mathrm{g}$ for stem extract, and $137.12 \mathrm{mg}$ GAE/g for fresh leaf extract. These figures suggest that TA extracts have an abundant quantity of polyphenols and are believed to possess bioactive compounds with potential antioxidant activity.

Our group's previous study revealed that owing to the presence of an abundant quantity of polyphenolic 
TABLE 2: Type of extraction used for extraction from medicinal plant TA and its yield ( $\mathrm{g} / 100 \mathrm{~g}$ of DW of powder) and total polyphenolic content of different parts of TA.

\begin{tabular}{lccc}
\hline S. no. & Medicinal plant organs & Extraction by stirring in methanol & Polyphenolic content (mg GAE/g DW) \\
\hline 1 & TA dry leaves & $12.7 \%^{*}$ & $409.92 \pm 6.03^{* *}$ \\
2 & TA fresh leaves & $9.87 \%^{*}$ & $137.12 \pm 5.01^{* *}$ \\
3 & TA stem & $8.34 \%^{*}$ & $141.75 \pm 4.21^{* *}$ \\
4 & TA root & $9.13 \%^{*}$ & $387.08 \pm 5.93^{* *}$ \\
\hline
\end{tabular}

Data shown as mean \pm SEM; $n=3,{ }^{*} p<0.05$, and ${ }^{* *} p<0.01$.

compounds in all four parts of TA extract and related species, they exhibited promising antioxidant activity by DPPH assay $[25,30]$. To support and validate the antioxidant potential of TA extracts, we evaluated the total antioxidant capacity (TAC) of all four TA extracts via phosphomolybdate assay. Our results demonstrated that the highest antioxidant capacity was shown by standard compound ascorbic acid (187.23 $\pm 10.34 \mathrm{mg}$ equivalents) followed by dry leaf extract (107.21 $\pm 5.38 \mathrm{mg}$ equivalents), root extract (105.72 $\pm 6.19 \mathrm{mg}$ equivalents), stem extract $(92.77 \pm 4.17 \mathrm{mg}$ equivalents), and fresh leaf extract (83.27 $\pm 5.31 \mathrm{mg}$ equivalents) (Figure 1 and Table 3 ). Additionally, our hydroxyl radical scavenging activity suggests that all four parts of TA extracts showed dosedependent antioxidant activity with $\mathrm{IC}_{50}$ value $50.19 \pm 3.34 \mu \mathrm{g} / \mathrm{mL}, \quad 51.33 \pm 3.51 \mu \mathrm{g} / \mathrm{mL}, \quad 59 \pm 3.67 \mu \mathrm{g} / \mathrm{mL}$, and $81.34 \pm 5.34 \mu \mathrm{g} / \mathrm{mL}$ for dry leaf, root, stem, and fresh leaf extract compared with standard compound ascorbic acid which has a $\mathrm{IC}_{50}$ value of $5.9 \pm 0.31 \mu \mathrm{g} / \mathrm{mL}$ (Table 3 ). Together, these results suggest that all four parts of TA extract exhibit promising antioxidant activity that is able to neutralize reactive oxygen species. In this way, protection against free radicals produced during metabolic reactions is offered.

3.2. In Vitro Toxicity Profile of TA Extracts on Human Skin Fibroblast (Hs27) Cells. Numerous reports suggest that the evaluation of cellular toxicity and protective effect of plant extracts is necessary to document whether the extract is safe to use against various harmful effects caused by free radicals [31]. Under physiological conditions, the free radicals and ROS are generated from aerobic metabolism [32]. If not efficiently neutralized by our antioxidant mechanism in our body, these oxidants are very reactive. They quickly interact with membrane proteins as well as intracellular components such as DNA molecules and cause damage which leads to a pathological state [33]. Free radicals and ROS are associated with numerous diseases which include neurodegenerative disease, cancer, diabetes, inflammation, and atherosclerosis [34]. Polyphenolic natural compounds have been documented as possessing antioxidant activity and have the potential to scavenge free radicals and ROS [35]. Plants are abundant sources of antioxidant polyphenols and other compounds such as tocopherol, phycocyanin, and essential fatty acids [36]. Natural compounds derived from plants can be used in remedies found in cosmetic products to enrich the antioxidant content of skin cells against free radicals and ROS generated by environmental toxicants [37].
A few years ago, Park et al. [38] demonstrated the importance of evaluating the toxicity profile of plant extract (Cordyceps militaris extract) using skin fibroblasts as a cellular model [38]. The study further reveals that exposure of dermal skin fibroblasts to $0.8 \mathrm{mM}$ dose of $\mathrm{H}_{2} \mathrm{O}_{2}$ for $3 \mathrm{~h}$ reduces cell viability by $59 \%$ when compared with untreated control skin fibroblasts. However, pretreatment of dermal skin fibroblasts with Cordyceps militaris extract in a dosedependent way (50 to $100 \mu \mathrm{g} / \mathrm{mL}$ ) reduces the cell death of dermal skin fibroblasts significantly, thus preventing $\mathrm{H}_{2} \mathrm{O}_{2}$ mediated oxidative stress-mediated cell death. Consistent with these findings, the current study sought to investigate the in vitro toxicity and protection offered by TA extracts on a human skin fibroblast (Hs27). The experimental setup was designed for both dose- $(27.5,55,110$, and $220 \mu \mathrm{g} / \mathrm{mL})$ as well as time-dependent $(4,24$, and $48 \mathrm{~h})$ manner. We observed a significantly negligible toxicity at both lower and higher doses $\left(5-9 \%,{ }^{*} p<0.05\right)$ of TA extracts when Hs27 cells were exposed for $4 \mathrm{~h}$ in comparison to the untreated control (Figure 2). Similarly, when Hs27 fibroblasts were exposed for $24 \mathrm{~h}$, the toxicity of cells at lower doses was insignificant $(1-5 \%, p<0.05)$, whereas, at the highest dose $(220 \mu \mathrm{g} / \mathrm{mL})$, we found significant toxicity in the $23-26 \%$ range, $p<0.05$ (Figure 3 ). However, for $48 \mathrm{~h}$ time point, skin fibroblasts exposed to varying doses of TA extracts revealed that significant toxicity $(17-22 \%, 35-41 \% ; p<0.05)$ was observed at higher doses $(110,220 \mu \mathrm{g} / \mathrm{mL})$, respectively (Figure 4).

These results indicate that TA extracts at smaller doses have a small amount of bioactive substances and probably are diffused across the plasma membrane in low concentrations to impart any toxicity effect. Therefore, the highest doses of plant extract which are beyond the concentrations used in commercial products would have bioactive constituents in adequate quantities to be toxic. Intriguingly, the outcome of this effect depends on the duration of interaction between the extract components and the cells. Thus, this interaction will decide the uptake of bioactive components by cells and their impact on cell viability. Collectively, these results demonstrate that the lower doses of such plant extracts, firstly, display a safe toxicity profile and, secondly, are not deleterious to skin fibroblasts. Therefore, being incorporated into the commercial products in smaller doses will enhance their effectiveness.

The toxicity of cells upon being treated with larger doses of TA extract and longer exposure could be due to the presence of bioactive compounds present in the extract. Alternatively, the decrease in cell viability at higher doses could be due to the presence of some prooxidant activity, 


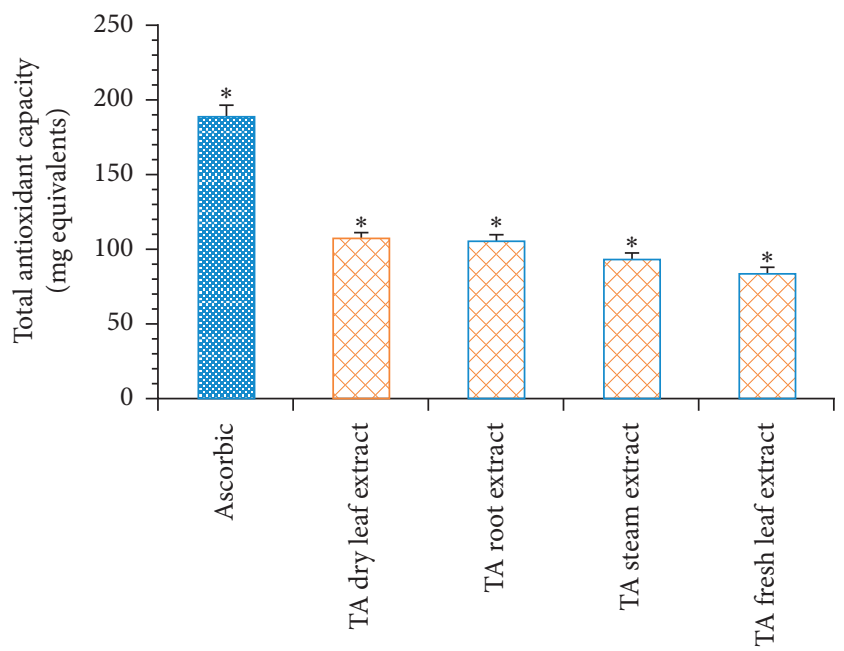

Figure 1: Total antioxidant capacity of all four parts (dry leaf, root, stem, and fresh leaf methanolic extract) of TA plant compared with standard compound ascorbic acid expressed in mg equivalents. Data represented as the mean \pm SEM; $n=3$ and ${ }^{*} p<0.05$.

TABle 3: Total antioxidant capacity and hydroxyl radical scavenging activity of different parts of TA along with standard compound ascorbic acid.

\begin{tabular}{|c|c|c|c|}
\hline $\begin{array}{l}\text { S. } \\
\text { no. }\end{array}$ & $\begin{array}{l}\text { Name of } \\
\text { samples }\end{array}$ & $\begin{array}{l}\text { Total antioxidant } \\
\text { capacity (mg } \\
\text { equivalents) }\end{array}$ & $\begin{array}{c}\text { Hydroxyl radical } \\
\text { scavenging activity } \\
\text { IC50 values }(\mu \mathrm{g} / \mathrm{mL})\end{array}$ \\
\hline 1 & $\begin{array}{l}\text { Ascorbic } \\
\text { acid }\end{array}$ & $187.23 \pm 10.34^{*}$ & $5.9 \pm 0.31^{*}$ \\
\hline 2 & $\begin{array}{c}\text { TA dry leaf } \\
\text { extract }\end{array}$ & $107.21 \pm 5.38^{*}$ & $50.19 \pm 3.34^{*}$ \\
\hline 3 & $\begin{array}{l}\text { TA root } \\
\text { extract }\end{array}$ & $105.72 \pm 6.19^{*}$ & $51.33 \pm 3.51^{*}$ \\
\hline 4 & $\begin{array}{l}\text { TA stem } \\
\text { extract }\end{array}$ & $92.77 \pm 4.17^{*}$ & $59 \pm 3.67^{*}$ \\
\hline 5 & $\begin{array}{l}\text { TA fresh } \\
\text { leaf extract }\end{array}$ & $83.27 \pm 5.31^{*}$ & $81.34 \pm 5.34^{*}$ \\
\hline
\end{tabular}

Data shown as mean \pm SEM; $n=3$ and ${ }^{*} p<0.05$.

and extortion of conditional media for a longer period of time $(48 \mathrm{~h})$ could increase the toxicity on skin fibroblasts; however, at lower doses, the prooxidant effect is negligible. This explanation is well supported by reports that the TA extracts exert a significant antiproliferative effect against a panel of human tumor cell lines at both dose- and timedependent contexts [25].

3.3. TA Extracts Induce Protection against $\mathrm{H}_{2} \mathrm{O}_{2}$-Mediated Oxidative Stress in Human Skin Fibroblasts. The generation of free radicals and ROS leads to oxidative stress which in turn leads to various ailments in the human body [39]. $\mathrm{H}_{2} \mathrm{O}_{2}$ is one of the most common forms of ROS, generated in the cellular models when exposed to UV radiation and pollutants. Depending on the level of $\mathrm{H}_{2} \mathrm{O}_{2}$ in the cellular system, it may help in wound healing by acting as a secondary messenger and remodulating signaling to repair damaged tissue. Nonetheless, excessive production of $\mathrm{H}_{2} \mathrm{O}_{2}$ may lead to inflammation and induce oxidative stress in cellular models [40]. Excessive production of $\mathrm{H}_{2} \mathrm{O}_{2}$ promotes oxidative damage to cellular models by augmenting MAPK-dependent cell death mechanisms [41]. Previous reports suggest that a significant increase in the $\mathrm{H}_{2} \mathrm{O}_{2}$ level and concomitant decrease in catalase activity was observed in dermal fibroblasts of aged human skin than the dermal fibroblasts of younger human skin [42].

The vulnerable targets of free radicals and ROS are cell membrane, lipids, DNA, and proteins [43]. Under oxidative stress conditions, the body's own antioxidant system is not sufficient to neutralize free radicals and ROS effectively; hence, it is dependent on exogenous sources [44]. Owing to the presence of high antioxidant compounds, the plants are the main exogenous source of antioxidants in the form of fruits, dietary products, and cosmetic products derived from natural sources to enrich the antioxidant level in our body to neutralize free radicals and ROS effectively $[45,46]$. Various plant extracts can display antioxidant potential by neutralizing free radicals produced during physiological reactions [47]. Therefore, we exposed Hs27 cells to varying concentrations $(27.5,55,110$, and $220 \mu \mathrm{g} / \mathrm{mL})$ of TA extract for different time points $(4,24$, and $48 \mathrm{~h})$, followed by $300 \mu \mathrm{M}$ of $\mathrm{H}_{2} \mathrm{O}_{2}$ exposure for $1 \mathrm{~h}[48,49]$, to evaluate the protective effect of TA extract. The cell killing induced by $\mathrm{H}_{2} \mathrm{O}_{2}$-mediated by oxidative stress in untreated cells was significantly different from cells pretreated with TA extract in both dose- and time-dependent ways. Owing to the production of ROS, the percentage of cell viability varies when $\mathrm{H}_{2} \mathrm{O}_{2}$-mediated oxidative stress was induced. Pretreatment with TA extracts offers significant protection at higher concentrations as well as different time points in skin fibroblasts against $\mathrm{H}_{2} \mathrm{O}_{2}$-mediated cell death.

Previous studies revealed that quercetin reduces the oxidative damage of skin cells by acting as a powerful protectant against $\mathrm{H}_{2} \mathrm{O}_{2}$-mediated oxidative insults and effectively protects cell death mechanisms at a $50 \mu \mathrm{M}$ dose [50]. Therefore, we use quercetin as the positive control in our study to evaluate the level of protection against $\mathrm{H}_{2} \mathrm{O}_{2}$ mediated oxidative stress. In comparison to TA extracts, the 


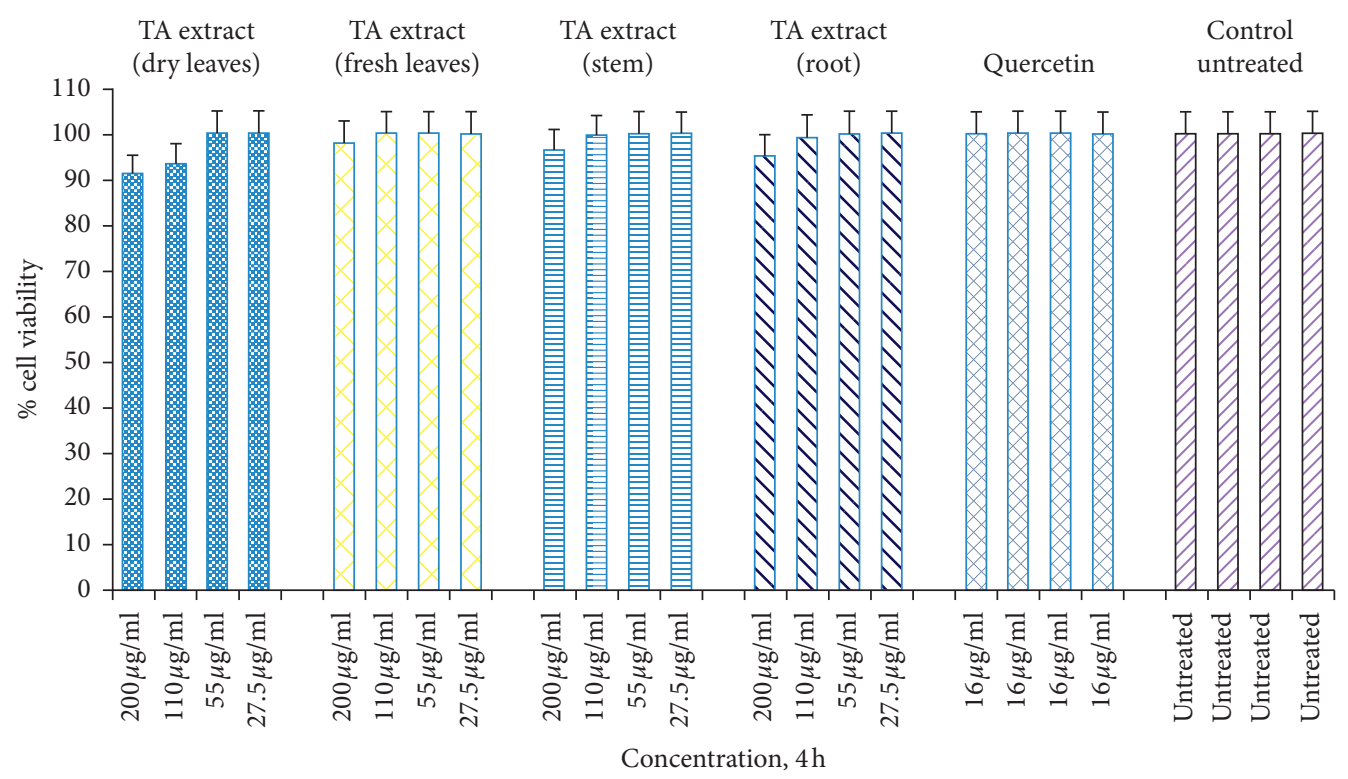

FIgURE 2: Cell viability determined by MTT assay. Hs27 skin fibroblasts were seeded at a density of 10,000 cells/well in 96-well plates and allowed to incubate overnight to attach to the surface. Next day, treat the cells with TA extracts (fresh and dry leaf, stem, and root extracts) for $4 \mathrm{~h}$ along with quercetin as a positive control $(16 \mu \mathrm{g} / \mathrm{mL})$ and control as untreated. Data shown as mean $\pm \mathrm{SEM} ; n=3$ and ${ }^{*} p<0.05$.

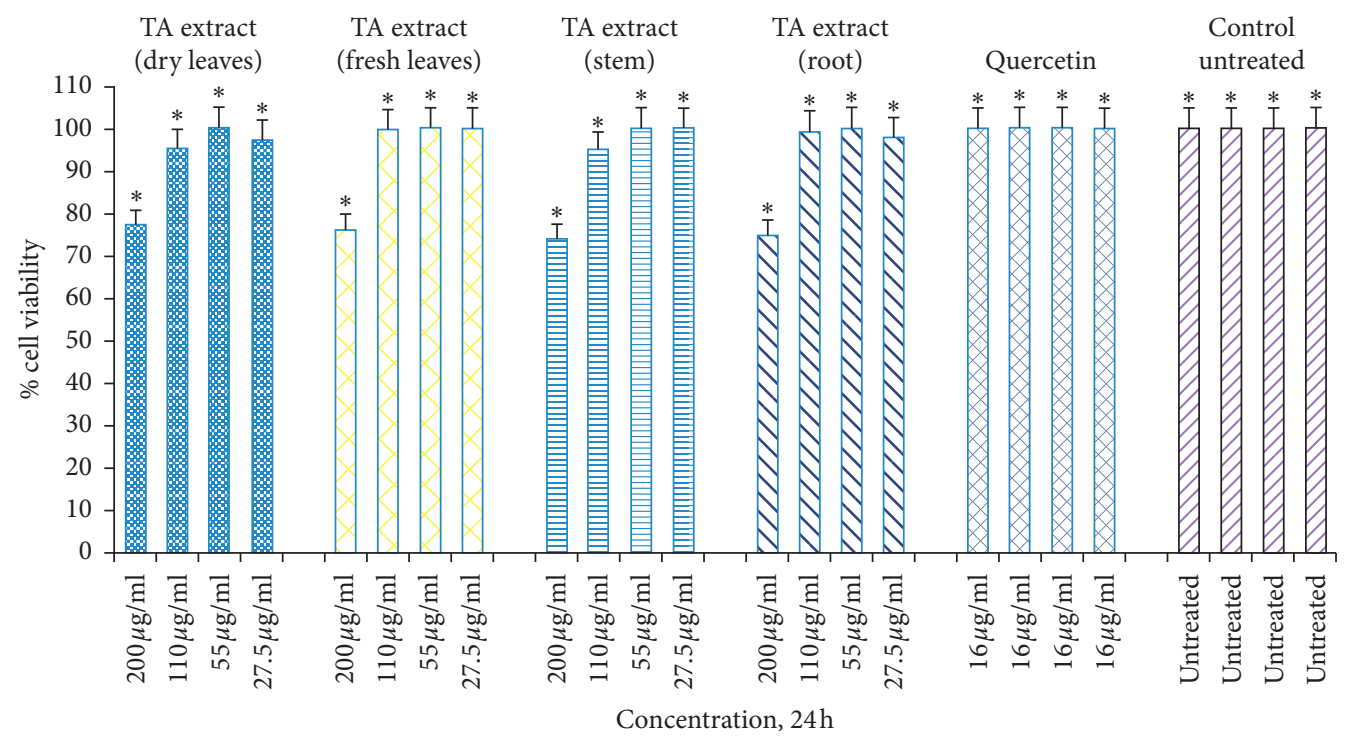

Figure 3: Cell viability determined by MTT assay. Hs27 skin fibroblasts were seeded at a density of 10,000 cells/well in 96-well plates and allowed to incubate overnight to attach to the surface. Next day, treat the cells with TA extracts (fresh and dry leaf, stem, and root extracts) for $24 \mathrm{~h}$ along with quercetin as a positive control $(16 \mu \mathrm{g} / \mathrm{mL})$ and control as untreated. Data shown as mean \pm SEM; $n=3$ and * $p<0.05$.

positive control quercetin $(16 \mu \mathrm{g} / \mathrm{mL})$ protects cells significantly at all time points when exposed to $\mathrm{H}_{2} \mathrm{O}_{2}$-mediated oxidative stress for $1 \mathrm{~h}$. Pretreatment with varying doses $(27.5,55,110$, and $220 \mu \mathrm{g} / \mathrm{mL})$ of TA extract for $4 \mathrm{~h}$, followed by $\mathrm{H}_{2} \mathrm{O}_{2}$-mediated oxidative insult, offers protection in a dose-dependent manner. Significant protection (11-17\%) was offered at $220 \mu \mathrm{g} / \mathrm{mL}$, followed by $6-9 \%$ at $110 \mu \mathrm{g} / \mathrm{mL}$; however, positive control quercetin offers $42-45 \%$ protection against $\mathrm{H}_{2} \mathrm{O}_{2}$-mediated oxidative stress (Figure 5).
As evidenced by the high survival percentage of Hs27 fibroblasts in solely TA extract treatment compared to pretreatment with TA, this was followed by $\mathrm{H}_{2} \mathrm{O}_{2}$-mediated oxidative stress (Figures 2 and 5). Similarly, significant protection at $14-15 \%$ and $25-33 \%$ at doses of $110 \mu \mathrm{g} / \mathrm{mL}$ and $220 \mu \mathrm{g} / \mathrm{mL}$, respectively, were noticed when Hs27 fibroblasts were pretreated with TA extract for $24 \mathrm{~h}$ followed by oxidative stress with $\mathrm{H}_{2} \mathrm{O}_{2}$ for $1 \mathrm{~h}$ (Figure 6). Although we observe a maximum cell toxicity 


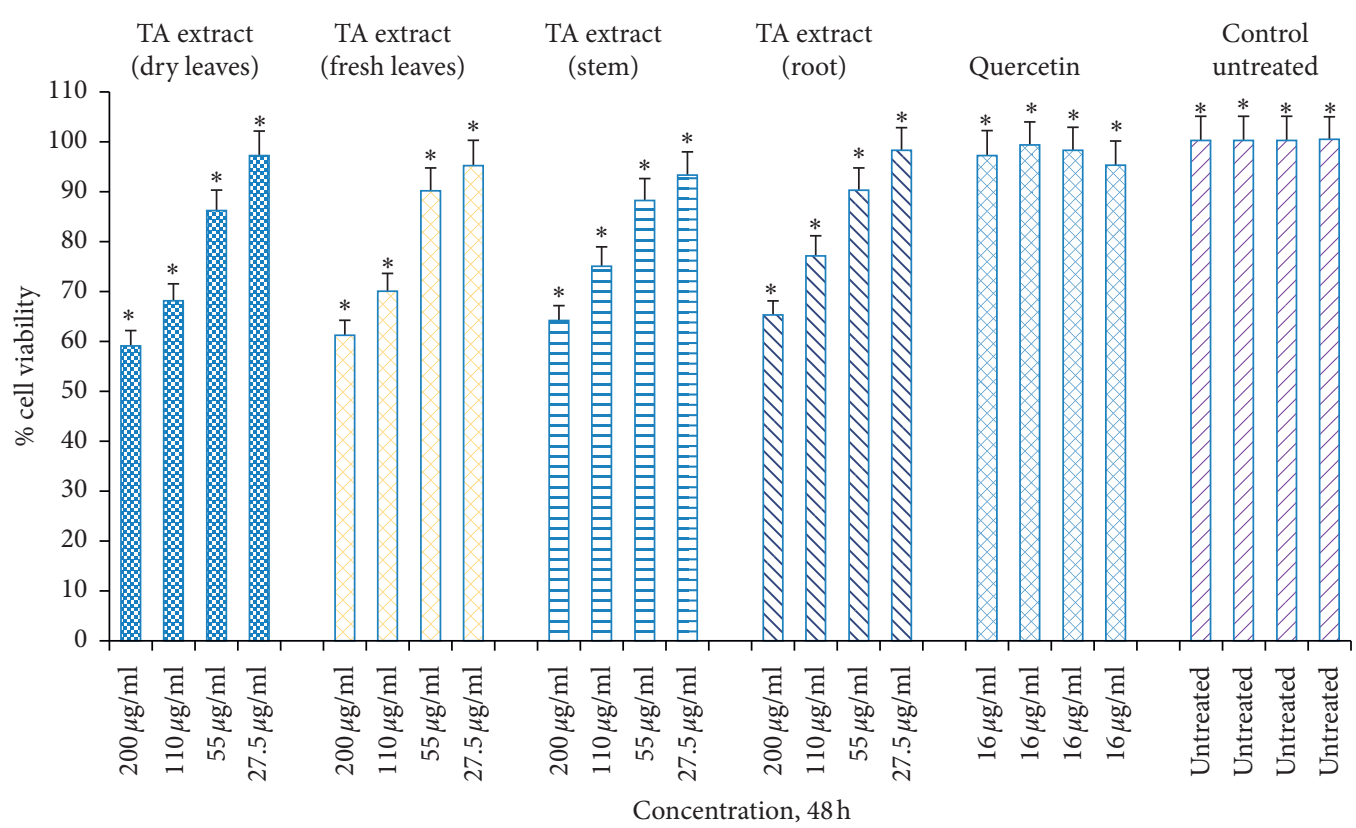

FIGURE 4: Cell viability determined by MTT assay. Hs27 skin fibroblasts were seeded at a density of 10,000 cells/well in 96-well plates and allowed to incubate overnight to attach to the surface. Next day, treat the cells with TA extracts (fresh and dry leaf, stem, and root extracts) for $48 \mathrm{~h}$ along with quercetin as a positive control $(16 \mu \mathrm{g} / \mathrm{mL})$ and control as untreated. Data shown as mean \pm SEM; $n=3$ and ${ }^{*} p<0.05$.

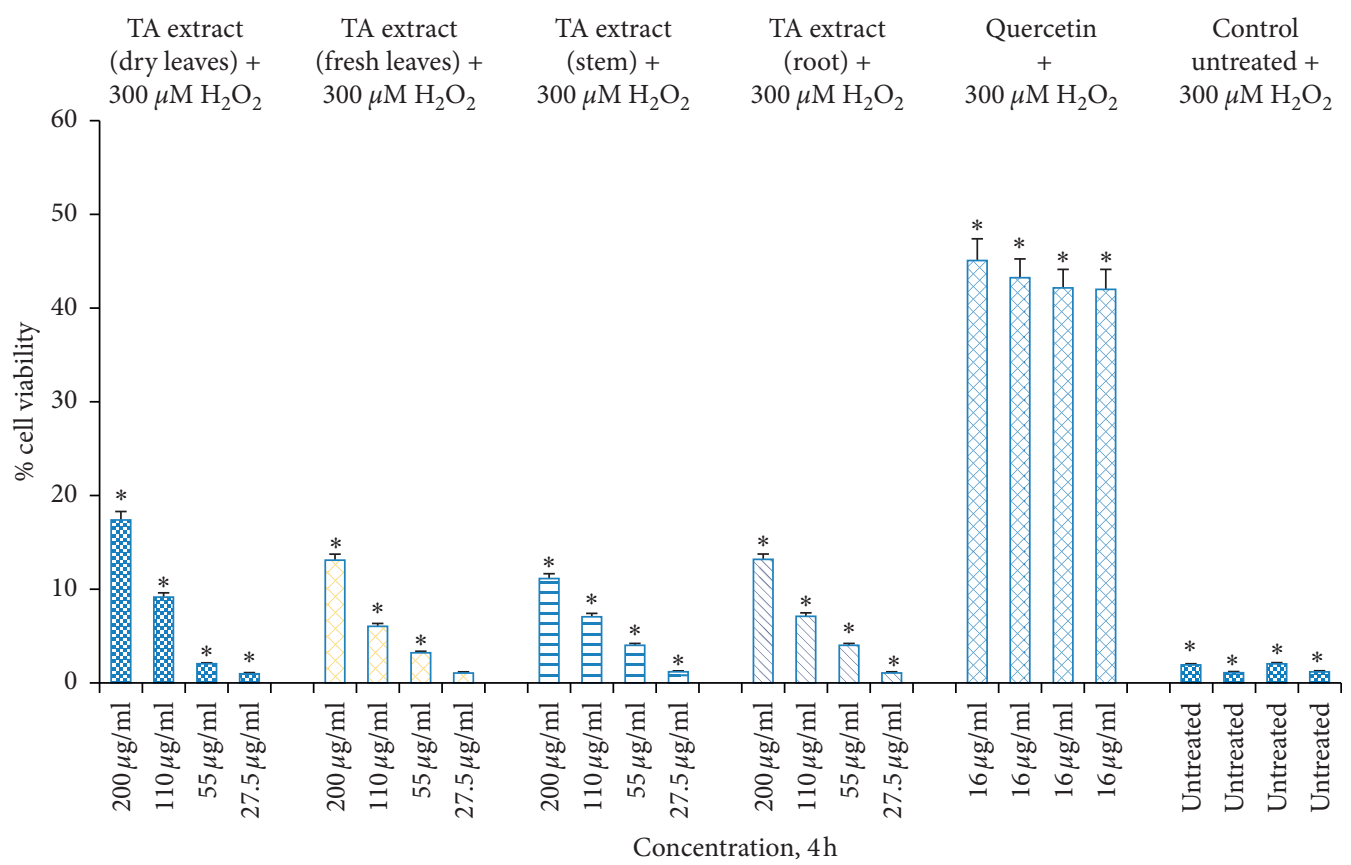

FIGURE 5: Cell viability determined by MTT assay. Hs27 skin fibroblasts were seeded at a density of 10,000 cells/well in 96-well plates and allowed to incubate overnight to attach to the surface. Next day, treat the cells with TA extracts (fresh and dry leaf, stem, and root extracts) for $4 \mathrm{~h}$ along with quercetin as a positive control $(16 \mu \mathrm{g} / \mathrm{mL})$ and control as untreated. After the completion of treatment, expose the pretreated cells with $300 \mu \mathrm{M}$ of $\mathrm{H}_{2} \mathrm{O}_{2}$ for $1 \mathrm{~h}$. Data shown as mean \pm SEM; $n=3,{ }^{*} p<0.05$.

effect after $48 \mathrm{~h}$ of treatment with larger doses of TA extract alone (Figure 4), pretreatment of $\mathrm{Hs} 27$ cells with TA extracts in a dose-dependent way for $48 \mathrm{~h}$ was followed by $1 \mathrm{~h}$ exposure to $\mathrm{H}_{2} \mathrm{O}_{2}$-mediated oxidative stress. We observed significant protection at $16-23 \%, 26-34 \%$, and $39-44 \%$ at doses of $55 \mu \mathrm{g} / \mathrm{mL}, 110 \mu \mathrm{g} / \mathrm{mL}$, and $220 \mu \mathrm{g} /$
$\mathrm{mL}$, respectively (Figure 7). The relative cell survival after pretreatment with TA extracts followed by exposure to $\mathrm{H}_{2} \mathrm{O}_{2}$ for $1 \mathrm{~h}$ was significantly higher than untreated cells following exposure to $\mathrm{H}_{2} \mathrm{O}_{2}$. The high percentage of protection offered to $\mathrm{Hs} 27$ fibroblasts after $48 \mathrm{~h}$ exposure to TA extracts followed by oxidative stress-induced by 


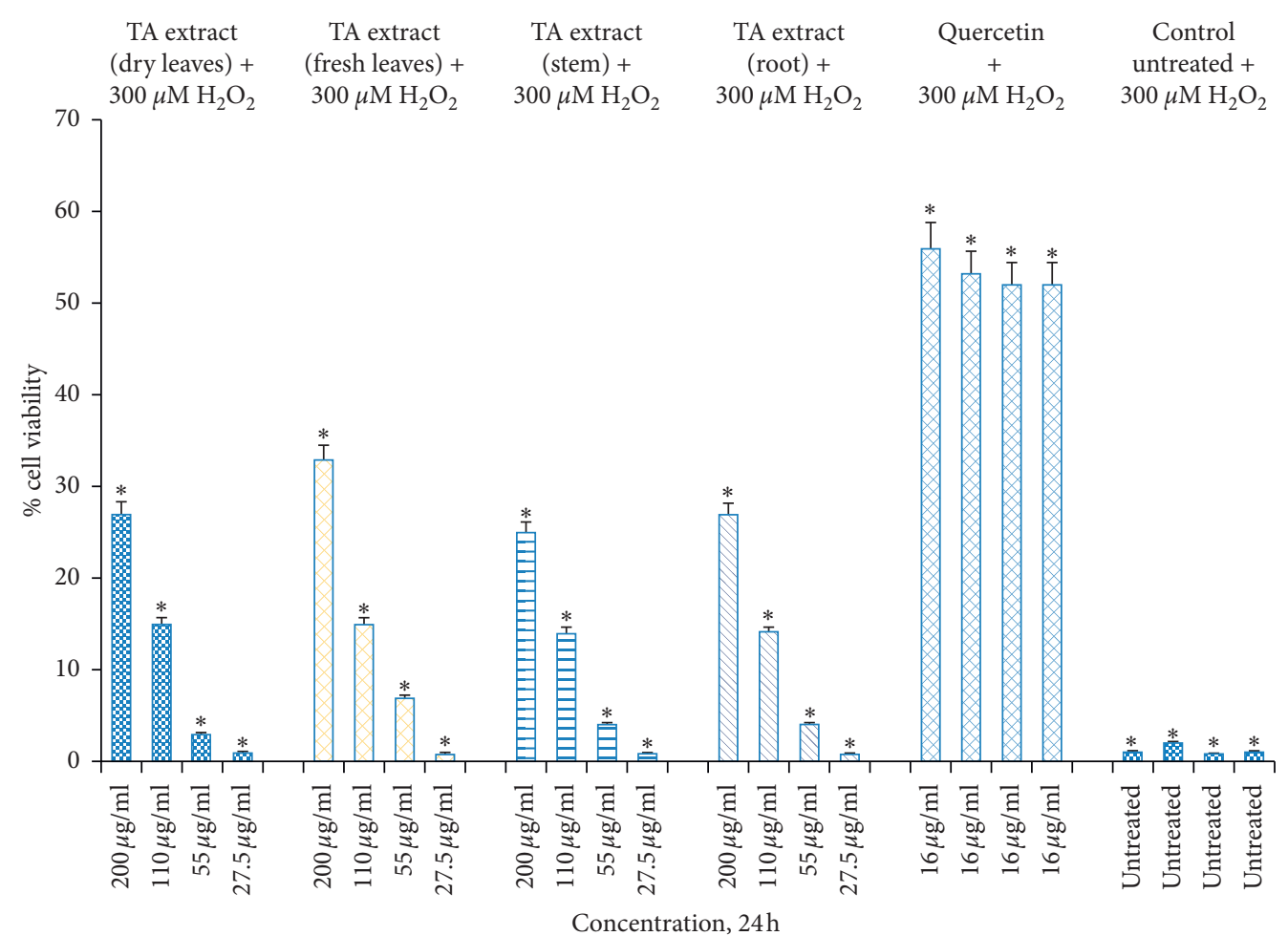

Figure 6: Cell viability determined by MTT assay. Hs27 skin fibroblasts were seeded at a density of 10,000 cells/well in 96-well plates and allowed to incubate overnight to attach to the surface. Next day, treat the cells with TA extracts (fresh and dry leaf, stem, and root extracts) for $24 \mathrm{~h}$ along with quercetin as positive control $(16 \mu \mathrm{g} / \mathrm{mL})$ and control as untreated. After the completion of treatment, expose the pretreated cells with $300 \mu \mathrm{M}$ of $\mathrm{H}_{2} \mathrm{O}_{2}$ for $1 \mathrm{~h}$. Data shown as mean \pm SEM; $n=3,{ }^{*} p<0.05$.

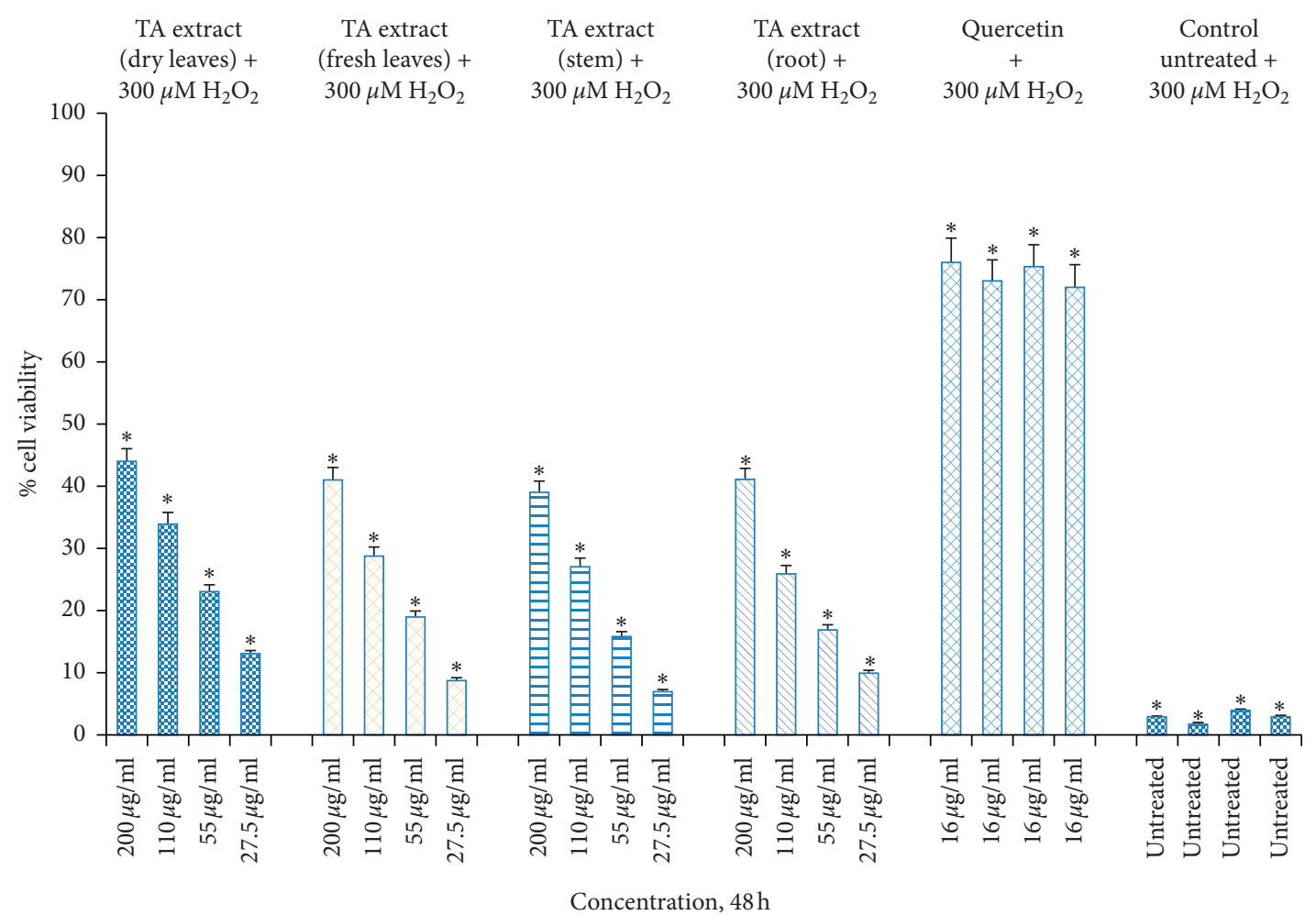

FIGURE 7: Cell viability determined by MTT assay. Hs27 skin fibroblasts were seeded at a density of 10,000 cells/well in 96-well plates and allowed to incubate overnight to attach to the surface. Next day, treat the cells with TA extracts (fresh and dry leaf, stem, and root extracts) for $48 \mathrm{~h}$ along with quercetin as a positive control $(16 \mu \mathrm{g} / \mathrm{mL})$ and control as untreated. After the completion of treatment, expose the pretreated cells with $300 \mu \mathrm{M}$ of $\mathrm{H}_{2} \mathrm{O}_{2}$ for $1 \mathrm{~h}$. Data shown as mean \pm SEM; $n=3,{ }^{*} p<0.05$. 
$\mathrm{H}_{2} \mathrm{O}_{2}$ could be due to enough time being required for bioactive compounds. These are present in TA extract and can enter the cells and offer protection by neutralizing free radicals generated during exposure to $\mathrm{H}_{2} \mathrm{O}_{2}$. Although the higher concentrations for a longer period of time show significant cell death, at lower doses for a longer time point, they do not exhibit toxic effects to Hs27 fibroblasts. Nonetheless, they permit bioactive compounds to pass through the cell membrane. These bioactive compounds have antioxidant potential and protect cells against any exposure to free radicals generated by $\mathrm{H}_{2} \mathrm{O}_{2}$.

\section{Conclusion}

The present study demonstrates that all four parts of TA extracts contain large amounts of polyphenolic bioactive compounds and exhibit promising antioxidant potential. Dose- and time-dependent exposure of skin fibroblasts (Hs27 cells) to TA extracts reveals a negligible cytotoxicity to Hs27 cells when exposed for $4 \mathrm{~h}$. However, $24 \mathrm{~h}$ and $48 \mathrm{~h}$ TA extract treatment to Hs27 cells exhibits significant toxicity. Additionally, we observe that TA extracts offer protection to $\mathrm{Hs} 27$ skin fibroblasts against free radicals generated by $\mathrm{H}_{2} \mathrm{O}_{2}$-mediated oxidative stress. These kinds of extracts can potentially be used in cosmetic products to offer protection to skin fibroblasts against free radicals generated by environmental toxicants and UV radiation. However, further research is very much needed to evaluate the underlying mechanism for the protective effect of TA extracts (dry leaf extract) using human skin fibroblasts as cellular models.

\section{Abbreviations}

$\begin{array}{ll}\text { ROS: } & \text { Reactive oxygen species } \\ \mathrm{H}_{2} \mathrm{O}_{2}: & \text { Hydrogen peroxide } \\ \text { FCR: } & \text { Folin-Ciocalteu reagent } \\ \text { DPPH: } & \text { 1,1-Diphenyl-2-picryl-hydroxyl } \\ \text { DMSO: } & \text { Dimethyl sulphoxide } \\ \text { MTT: } & \text { 3-(4,5-Dimethylthiazol-2-yl)-2,5- } \\ & \text { diphenyltetrazolium bromide } \\ \text { FBS: } & \text { Fetal bovine serum } \\ \text { PBS: } & \text { Phosphate-buffered saline } \\ \text { QE: } & \text { Quercetin } \\ \text { GA: } & \text { Gallic acid } \\ \text { SE: } & \text { Standard error } \\ \mathrm{ANOVA}: & \text { Analysis of variance } \\ \mathrm{Na}_{2} \mathrm{CO}_{3}: & \text { Gallic acid }\end{array}$

\section{Data Availability}

The data used to support the study are available upon request to the corresponding author.

\section{Conflicts of Interest}

The authors declare that they have no conflicts of interest.

\section{Acknowledgments}

The researcher would like to thank Dr. Ohoud Alshehri, Ibn Sina National College for Medical Studies, and Dr. Bilal Rah, postdoc, Qassim University, College of Applied Medical Sciences, for their support.

\section{References}

[1] R. Ravindran, M. K. Swamy, and R. Jaganathan, “Therapeutic potential of plant polyphenolics and their mechanistic action against various diseases," Natural Bio-Active Compounds, pp. 313-351, 2019.

[2] T. Hussain, B. Tan, Y. Yin, F. Blachier, M. C. Tossou, and N. Rahu, "Oxidative stress and inflammation: what polyphenols can do for us?" Oxidative Medicine and Cellular Longevity, vol. 2016, Article ID 7432797, 9 pages, 2016.

[3] V. Lobo, A. Patil, A. Phatak, and N. Chandra, "Free radicals, antioxidants and functional foods: impact on human health," Pharmacognosy Reviews, vol. 4, no. 8, p. 118, 2010.

[4] P. S. Rao, S. Kalva, A. Yerramilli, and S. Mamidi, "Free radicals and tissue damage: role of antioxidants," Free Radicals and Antioxidants, vol. 1, no. 4, pp. 2-7, 2011.

[5] J. E. NigamPrakash Mishra, J. J. Shacka, M. I. Sweeney, and J. T. Weber, "Antioxidants and free radical scavengers for the treatment of stroke, traumatic brain injury and aging," Current Medicinal Chemistry, vol. 15, no. 4, pp. 404-414, 2008.

[6] S. R. Ahmad, P. Gokulakrishnan, R. Giriprasad, and M. A. Yatoo, "Fruit-based natural antioxidants in meat and meat products: a review," Critical Reviews in Food Science and Nutrition, vol. 55, no. 11, pp. 1503-1513, 2015.

[7] D. Krishnaiah, R. Sarbatly, and R. Nithyanandam, "A review of the antioxidant potential of medicinal plant species," Food and Bioproducts Processing, vol. 89, no. 3, pp. 217-233, 2011.

[8] B. Salehi, E. Azzini, P. Zucca et al., "Plant-derived bioactives and oxidative stress-related disorders: a key trend towards healthy aging and longevity promotion," Applied Sciences, vol. 10 , no. 3, p. 947.

[9] F. M. F. Roleira, E. J. Tavares-da-Silva, C. L. Varela et al., "Plant derived and dietary phenolic antioxidants: anticancer properties," Food Chemistry, vol. 183, pp. 235-258, 2015.

[10] B.-T. Kim, J.-C. Chun, and K.-J. Hwang, "Synthesis of dihydroxylated chalcone derivatives with diverse substitution patterns and their radical scavenging ability toward DPPH free radicals," Bulletin of the Korean Chemical Society, vol. 29, no. 6, pp. 1125-1130, 2008.

[11] H. A. Abulafatih, "Medicinal plants in southwestern Saudi Arabia," Economic Botany, vol. 41, no. 3, pp. 354-360, 1987.

[12] R. Ksouri, H. Falleh, W. Megdiche et al., "Antioxidant and antimicrobial activities of the edible medicinal Halophyte tamarix gallica L. and related polyphenolic constituents," Food and Chemical Toxicology, vol. 47, no. 8, pp. 2083-2091, 2009.

[13] R. Arianmanesh, I. Mehregan, M. Assadi, and T. Nejadsattari, "Comparative morphology of the Genus tamarix (tamaricaceae) in Iran," International Letters of Natural Sciences, vol. 60, 2016.

[14] M. Eddouks, M. Maghrani, A. Lemhadri, M.-L. Ouahidi, and H. Jouad, "Ethnopharmacological survey of medicinal plants used for the treatment of diabetes mellitus, hypertension and cardiac diseases in the south-east region of Morocco (tafilalet)," Journal of Ethnopharmacology, vol. 82, no. 2-3, pp. 97-103, 2002. 
[15] M. Hebi, O. Farid, M. Ajebli, and M. Eddouks, "Potent antihyperglycemic and hypoglycemic effect of Tamarix articulata vahl. in normal and streptozotocin-induced diabetic rats," Biomedicine \& Pharmacotherapy, vol. 87, pp. 230-239, 2017.

[16] B. Badhani, N. Sharma, and R. Kakkar, "Gallic acid: a versatile antioxidant with promising therapeutic and industrial applications," RSC Advances, vol. 5, no. 35, pp. 27540-27557, 2015.

[17] A. El-SeediKhalifa and A. K. Saluja, "The pharmacological potential of rutin," Saudi Pharmaceutical Journal, vol. 25, no. 2, pp. 149-164, 2017.

[18] R. Chen, Q.-L. Qi, M.-T. Wang, and Q.-Y. Li, "Therapeutic potential of naringin: an overview," Pharmaceutical Biology, vol. 54, no. 12, pp. 3203-3210, 2016.

[19] G. E.-S. Batiha, A. M. Beshbishy, M. Ikram et al., "The pharmacological activity, biochemical properties, and pharmacokinetics of the major natural polyphenolic flavonoid: Quercetin," Foods, vol. 9, no. 3, p. 374, 2020.

[20] M. Naveed, V. Hejazi, M. Abbas et al., "Chlorogenic acid (CGA): a pharmacological review and call for further research," Biomedicine \& Pharmacotherapy, vol. 97, pp. 67-74, 2018.

[21] A. Tabet, A. Boukhari, and Y. Nouidjem, "Phenolic content, HPLC analysis and antioxidant activity extract from Tamarix articulata," Journal of Advanced Pharmacy Education \& Research|, vol. 8, no. 4, 2018.

[22] M. Ali, H. A. Alhazmi, S. Ansari et al., "Tamarix aphylla (1.) karst. Phytochemical and bioactive profile compilations of less discussed but effective naturally growing Saudi plant," Plant and Human Health, vol. 3, pp. 343-352, 2019.

[23] A. M. Alnuqaydan and B. Rah, "Tamarix articulata (T. articulata)-an important halophytic medicinal plant with potential pharmacological properties," Current Pharmaceutical Biotechnology, vol. 20, no. 4, pp. 285-292, 2019.

[24] A. M. Alnuqaydan and B. Rah, "Comparative assessment of biological activities of different parts of halophytic plant tamarix articulata (T. articulata) growing in Saudi Arabia," Saudi Journal of Biological Sciences, vol. 27, no. 10, pp. 2586-2592, 2020.

[25] W. A. Wannes, B. Mhamdi, J. Sriti et al., "Antioxidant activities of the essential oils and methanol extracts from myrtle (Myrtus communis var. Italica L.) leaf, stem and flower," Food and Chemical Toxicology, vol. 48, no. 5, pp. 1362-1370, 2010.

[26] A. C. de Oliveira, I. B. Valentim, C. A. Silva et al., "Total phenolic content and free radical scavenging activities of methanolic extract powders of tropical fruit residues," Food Chemistry, vol. 115, no. 2, pp. 469-475, 2010.

[27] P. Prieto, M. Pineda, and M. Aguilar, "Spectrophotometric quantitation of antioxidant capacity through the formation of a phosphomolybdenum complex: specific application to the determination of vitamin E," Analytical Biochemistry, vol. 269, no. 2, pp. 337-341, 1999.

[28] S. M. Klein, G. Cohen, and A. I. Cederbaum, "Production of formaldehyde during metabolism of dimethyl sulfoxide by hydroxyl radical-generating systems," Biochemistry, vol. 20, no. 21, pp. 6006-6012, 1981.

[29] A. M. Alnuqaydan, B. Rah, A. G. Almutary, and S. S. Chauhan, "Synergistic antitumor effect of 5-fluorouracil and withaferina induces endoplasmic reticulum stress-mediated autophagy and apoptosis in colorectal cancer cells," American Journal of Cancer Research, vol. 10, no. 3, p. 799, 2020.

[30] A. S. Gadallah, S. Mujeeb-ur-Rehman, A. Atta-ur-Rahman et al., "Anti-inflammatory principles from Tamarix aphylla L.: a bioassay-guided fractionation study," Molecules, vol. 25, no. 13, p. 2994, 2020.

[31] W.-L. Chu, Y.-W. Lim, A. K. Radhakrishnan, and P.-E. Lim, "Protective effect of aqueous extract from spirulina platensis against cell death induced by free radicals," BMC Complementary and Alternative Medicine, vol. 10, no. 1, p. 53, 2010.

[32] I. Millán, J. Piñero-Ramos, I. Lara, A. Parra-Llorca, I. TorresCuevas, and M. Vento, "Oxidative stress in the newborn period: useful biomarkers in the clinical setting," Antioxidants, vol. 7, no. 12, p. 193, 2018.

[33] B. A. Aslani and S. Ghobadi, "Studies on oxidants and antioxidants with a brief glance at their relevance to the immune system," Life Sciences, vol. 146, pp. 163-173, 2016.

[34] S. Ghosh, S. Banerjee, and P. C. Sil, "The beneficial role of curcumin on inflammation, diabetes and neurodegenerative disease: a recent update," Food and Chemical Toxicology, vol. 83, pp. 111-124, 2015.

[35] D. M. Nagmoti, D. K. Khatri, P. R. Juvekar, and A. R. Juvekar, "Antioxidant activity free radical-scavenging potential of pithecellobium dulce benth seed extracts," Free Radicals and Antioxidants, vol. 2, no. 2, pp. 37-43, 2012.

[36] L. Andrade, C. Andrade, M. Dias, C. Nascimento, and M. Mendes, "Chlorella and spirulina microalgae as sources of functional foods," Nutraceuticals, and Food Supplements, vol. 6, no. 1, pp. 45-58, 2018.

[37] S. Oksana, M. Brestic, M. Rai, and H. Shao, "Plant phenolic compounds for food, pharmaceutical and cosmetics production," Journal of Medicinal Plants Research, vol. 6, no. 13, pp. 2526-2539, 2012.

[38] J. Park, J. Lee, K. Lee, S.-J. Ha, and E. Hong, "Cordyceps militaris extract protects human dermal fibroblasts against oxidative stress-induced apoptosis and premature senescence," Nutrients, vol. 6, no. 9, pp. 3711-3726, 2014.

[39] A. H. Bhat, K. B. Dar, S. Anees et al., "Oxidative stress, mitochondrial dysfunction and neurodegenerative diseases; a mechanistic insight," Biomedicine \& Pharmacotherapy, vol. 74, pp. 101-110, 2015.

[40] G. Zhu, Q. Wang, S. Lu, and Y. Niu, "Hydrogen peroxide: a potential wound therapeutic target," Medical Principles and Practice, vol. 26, no. 4, pp. 301-308, 2017.

[41] N. Ismail, M. Ismail, N. H. Azmi, M. F. Abu Bakar, H. Basri, and M. A. Abdullah, "Modulation of hydrogen peroxide-induced oxidative stress in human neuronal cells by thymoquinone-rich fraction and thymoquinone via transcriptomic regulation of antioxidant and apoptotic signaling genes," Oxidative Medicine and Cellular Longevity, vol. 2016, Article ID 2528935, 15 pages, 2016.

[42] H. J. Hahn, K. B. Kim, I.-S. An, K. J. Ahn, and H. J. Han, "Protective effects of rosmarinic acid against hydrogen peroxide-induced cellular senescence and the inflammatory response in normal human dermal fibroblasts," Molecular Medicine Reports, vol. 16, no. 6, pp. 9763-9769, 2017.

[43] A. Phaniendra, D. B. Jestadi, and L. Periyasamy, "Free radicals: properties, sources, targets, and their implication in various diseases," Indian Journal of Clinical Biochemistry, vol. 30, no. 1, pp. 11-26, 2015.

[44] S. Bhattacharya, "Reactive oxygen species and cellular defense system," incollection Free Radicals in Human Health and Disease, pp. 17-29, Springer, Berlin, Germany, 2015.

[45] N. Baenas, C. García-Viguera, and D. Moreno, "Elicitation: a tool for enriching the bioactive composition of foods," Molecules, vol. 19, no. 9, pp. 13541-13563, 2014. 
[46] A. Ribeiro, M. Estanqueiro, M. Oliveira, and J. Sousa Lobo, "Main benefits and applicability of plant extracts in skin care products," Cosmetics, vol. 2, no. 2, pp. 48-65, 2015.

[47] A. Rafat, K. Philip, and S. Muni, "Antioxidant potential and content of phenolic compounds in ethanolic extracts of selected parts of andrographis paniculata," Journal of Medicinal Plants Research, vol. 4, no. 3, pp. 197-202, 2010.

[48] A. Alnuqaydan, C. Lenehan, and R. Hudges Ramsay, "Calendula officinalis extracts protect against $\mathrm{H}_{2} \mathrm{O}_{2}$ induced chromosome damage on hacat human skin cells," Journal of Carcinogenesis \& Mutagenesisc, vol. 6, no. 6, 2015.

[49] R. Morabito, O. Romano, G. La Spada, and A. Marino, " $\mathrm{H}_{2} \mathrm{O}_{2}$ induced oxidative stress affects $\mathrm{SO}_{4}{ }^{=}$transport in human erythrocytes," PLoS One, vol. 11, no. 1, Article ID e0146485, 2016.

[50] A. Svobodová, D. Walterová, and J. Psotová, "Influence of silymarin and its flavonolignans on $\mathrm{H}_{2} \mathrm{O}_{2}$-induced oxidative stress in human keratinocytes and mouse fibroblasts," Burns, vol. 32, no. 8, pp. 973-979, 2006. 